\title{
Rehabilitasi Kolong Pasca Penambangan Timah dengan Teknologi Pertanian Terapung pada Budidaya Tanaman Selada Merah Keriting di Provinsi Bangka Belitung
}

\author{
Rehabilitation of Pit after Tin Mining by Floating Agricultural Technology at Red Curly \\ Lettuce Cultivation in the Bangka Belitung Province \\ Syafrullah Syafrullah ${ }^{1 *}$, Heniyati Hawalid ${ }^{1}$, Minwal Minwal ${ }^{1}$, Neni Marlina ${ }^{2}$ \\ ${ }^{1}$ Fakultas Pertanian, Universitas Muhammadiyah Palembang, Kota Palembang, \\ Sumatera Selatan 30263 \\ ${ }^{2}$ Fakultas Pertanian, Universitas Palembang, Kota Palembang, Sumatera Selatan 30139 \\ ${ }^{*}$ Penulis untuk korespondensi: syafrullahagro@yahoo.com
}

\begin{abstract}
Bangka Belitung Province is the largest tin producer in Indonesia. After tin mining was formed pit/under the surface of the earth . This pit potential was quite large, especially under the colonies near the settlement, in addition to fishery business could also be used with floating plant cultivation. The purpose of this research was to get location-specific cultivation technology of location specific plant at pit after tin mining which was floating plant cultivation technology and utilize the pit after tin mining to be productive pit for cultivation of vegetable crops and preserve the environment by utilizing the pit, plastic waste and grass became useful in the cultivation of floating vegetable crops at the pit after tin mining. This research was conducted from January to May 2016 in Batu Belubang Village, Pangkalan Baru District, Central Bangka Regency of Bangka Belitung Province. The design used was Factor Randomized Random Design (RAK) with 9 treatment combinations repeated 3 times and 5 sample plants. As the indicator plant was red curly lettuce. The treatments were 1) Type of raft (R) with 3 levels, those are $R_{1}=$ raft of plastic waste size of $250 \mathrm{ml}, \mathrm{R}_{2}=$ raft of plastic waste size of $600 \mathrm{ml}, \mathrm{R}_{3}=$ raft of plastic waste size of $1500 \mathrm{ml}$ and 2) compost type (X) with 3 levels ,namely $\mathrm{K}_{1}=$ compost of purun grass $\mathrm{K}_{2}=$ compost of bakung grass and $\mathrm{K}_{3}=$ compost of gegas grass. From the results of the research showed that the type of plastic waste raft size of $250 \mathrm{ml}$ and type of bakung grass compost gave the better growth and production response for curly red lettuce and the application of technology cultivation of curly floating red lettuce plants at the pit after tin mining lead to give the same results and tend to higher if compared with the system of cultivation coventionally on the dry land.
\end{abstract}

Keywords: red curly lettuce, loating vegetable, raft, plastic waste, compost, pit after tin mining

\section{ABSTRAK}

Provinsi Bangka Belitung merupakan penghasil timah terbesar di Indonesia. Pasca penambangan timah terbentuklah kolong di permukaan bumi, kolong ini selain usaha perikanan dapat juga dimanfaatkan dengan budidaya tanaman terapung. Tujuan dari penelitian ini untuk mendapatkan teknologi budidaya tanaman spesifik lokasi pada kolong pasca penambangan timah dan mendayagunakan kolong pasca penambangan timah menjadi kolong yang produktif untuk budidaya pertanian tanaman sayuran serta melestarikan lingkungan dengan cara memanfaatkan kolong, limbah plastik dan rumput 
Rawamenjadi bermanfaat.Penelitian ini dilaksanakan pada bulan Januari sampai Mei 2017. di Desa Batu Belubang Kecamatan Pangkalan Baru Kabupaten Bangka Tengah Propinsi Bangka Belitung, Rancangan yang digunakan adalah Rancangan Acak Kelompok (RAK) Faktorial dengan 9 kombinasi perlakuan yang diulang 3 kali dan 5 tanaman contoh. Sebagai tanaman indikator adalah selada merah keriting. Adapun perlakuannya adalah 1) jenis rakit $(\mathrm{R})$ dengan 3 taraf yaitu $\mathrm{R}_{1}=$ rakit limbah gelas plastik ukuran $250 \mathrm{ml}, \mathrm{R}_{2}=$ rakit limbah botol plastik ukuran $600 \mathrm{ml}$ dan $\mathrm{R}_{3}=$ rakit limbah botol plastik ukuran $1500 \mathrm{ml}$ dan 2) jenis kompos $(\mathrm{K})$ dengan 3 taraf yaitu $\mathrm{K}_{1}=$ kompos rumput purun, $\mathrm{K}_{2}=$ kompos rumput bakung dan $\mathrm{K}_{3}=$ kompos rumput Gegas. Dari hasil penelitian bahwa jenis rakit limbah gelas plastik ukuran $250 \mathrm{ml}$ dan jenis kompos rumput bakung memberikan hasil pertumbuhan dan produksi yang lebih tertinggi, Bila dibandingkan dengan sistem budidaya secara konvensional.

Kata kunci: budidaya terapung, kolong pasca penambangan timah, selada merah keriting

\section{PENDAHULUAN}

Kegiatan penambangan timah menghasilkan kolong-kolong di permukaan bumi. Saat ini kolong-kolong ini dimanfaatkan untuk kegiatan perikanan. Usaha perikanan ini dapat dilakukan pada kolong-kolong yang berusia lebih dari 15 tahun atau kolong yang mempunyai akses ke sungai dan laut. Karena berdasarkan hasil penelitian terhadap kualitas air kolong, permasalahan krusial dari kualitas air kolong yang berusia kurang dari 15 tahun dan tidak memiliki aksesibilitas ke sungai dan laut adalah kandungan logam berat terutama kandungan timbal $(\mathrm{Pb})$, seng $(\mathrm{Zn})$, dan tembaga $(\mathrm{Cu})$.

Jumlah kolong yang ada di wilayah Bangka dan Belitung sebanyak 887 kolong dengan luas 1.712,65 hektar. Kolong yang keberadaannya berdekatan dengan pemukiman penduduk dan berair jernih ada sebanyak 141 kolong, hanya 38 kolong yang telah dimanfaatkan untuk usaha perikanan, pertanian, sumber air baku PDAM, dan rekreasi. Sisanya, yakni sebanyak 583 kolong belum dimanfaatkan secara optimal, dan banyak ditumbuhi berbagai jenis tumbuhan liar, antara lain Rumput bakung, gegas, purun, rumbia, gelam, nipah, dan ilalang (PT Timah 003).

Potensi kolong yang cukup besar ini, terutama kolong-kolong yang berada dekat pemukiman penduduk, sebaiknya selain dimanfaatkan untuk usaha perikanan dibagian bawahnya, dapat juga dimanfaatkan dipermukaannya dengan budidaya tanaman sayuran terapung. (Syafrullah 2004).

Pada teknologi Media Tetapungpada Budidaya tanaman sayuran terapung, Media tanamnya terdiri dari campuran tanah dan kompos sebagai media tanam yang diletakkan di atas Rakit. Bahan baku pupuk organik (kompos) yang tersedia dalam jumlah banyak di lokasi penelitian adalah rumput Rawa. Bahan bakudalami pembuatan rakit adalah bahan-bahan yang terdapat dilokasi yaitu; batang pisang. Batang bamboo dan limbah plastik air mineral. Adanya potensi kolong, rumput dan limbah plastik yang cukup besar, maka dilakukanlah penelitian ini untuk mengatasi masalah Lingkungan terutama logam berat $\mathrm{Pb}, \mathrm{Zn}$ dan $\mathrm{Cu}$ hasil penambangan Timah dengan melakukan budidaya tanaman sayuran karena unsur logam tersebut mengendap di dasar Kolong sehingga tanaman menyerap air nya saja, dengan demikian unsur logam tidak terserap oleh akar tanaman selada, sehingga selada aman untuk dikonsumsi (Syafrullah 2004).

Tanaman selada merupakan tanaman hortikultura atau semusim yang banyak mengandung air. Di konsumsi dalam bentuk segar dan dalam bentuk olahan. Komoditi ini merupakan sayuran daun yang digemari dan dibutuhkan setiap hari oleh masyarakat dan harganya di pasaran cukup tinggi dan stabil 
dibandingkan sayuran sejenis (Rukmana 2004).

Tujuan dari penelitian ini untuk mendapatkan teknologi budidaya tanaman spesifik lokasi pada kolong pasca penambangan timah yaitu teknologi Media Terapung pada budidaya tanaman selada merah keriting dan mendayagunakan kolong pasca penambangan timah menjadi kolong yang produktif untuk budidaya pertanian tanaman sayuran serta melestarikan lingkungan dengan cara memanfaatkan kolong, limbah plastik dan rumput-rumputan menjadi bermanfaat dalam kegiatan budidaya tanaman sayuran terapung pada kolong pasca penambangan timah.

\section{BAHAN DAN METODE}

Penelitian ini dilaksanakan bulan Januari sampai bulanMei 2016. Tempat penelitian di Desa Batu Berlubang, Kecamatan Pangkalan Baru, Kabupaten Bangka Tengah, Propinsi Bangka Belitung (Gambar 1). Bahan yang digunakan dalam penelitian ini adalah benih selada merah keriting, kompos dari bahan rumputrumputan (bakung, gegas, dan purun), EM4, gula, dedak, pupuk kandang, dan air. Sedangkan alat yang digunakan dalam penelitian ini antara lain cangkul, parang, tali rafia, palu, meteran, timbangan, limbah gelas plastik, limbah botol plastik ukuran $600 \mathrm{ml}$, limbah botol plastik ukuran 1500 $\mathrm{ml}$, gergaji, bambu, hand sprayer, ember, gayung, alat tulis, dan lain-lain.

Penelitian ini menggunakan

Rancangan Acak Kelompok (RAK) Faktorial dengan 9 kombinasi perlakuan yang diulang 3 kali dan 5 tanaman contoh sebagai tanaman indicator adalah selada merah keriting. Adapun perlakuannya adalah 1) jenis rakit (R) dengan 3 taraf yaitu $\mathrm{R}_{1}=$ rakit limbah gelas plastik ukuran 250 $\mathrm{ml}, \mathrm{R}_{2}=$ rakit limbah botol plastik ukuran $600 \mathrm{ml}$ dan $\mathrm{R}_{3}=$ rakit limbah botol plastik ukuran $1500 \mathrm{ml}$ dan 2) jenis kompos (K) dengan 3 taraf yaitu $\mathrm{K}_{1}=$ kompos rumput purun, $\mathrm{K}_{2}=$ kompos rumput bakung dan $\mathrm{K}_{3}=$ kompos rumput Gegas (Gambar 2 dan 3).

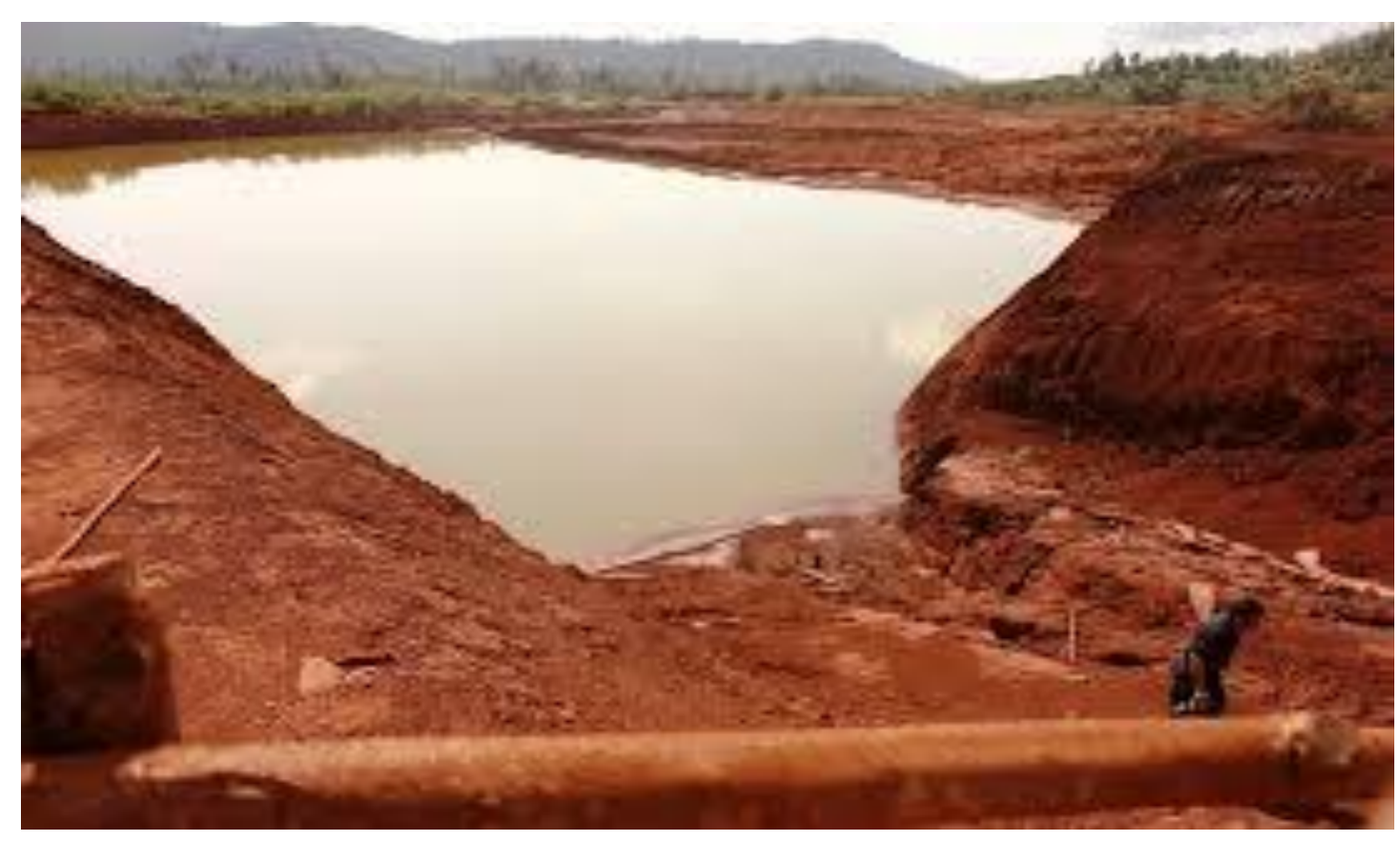

Gambar 1. Lokasi penelitian. 


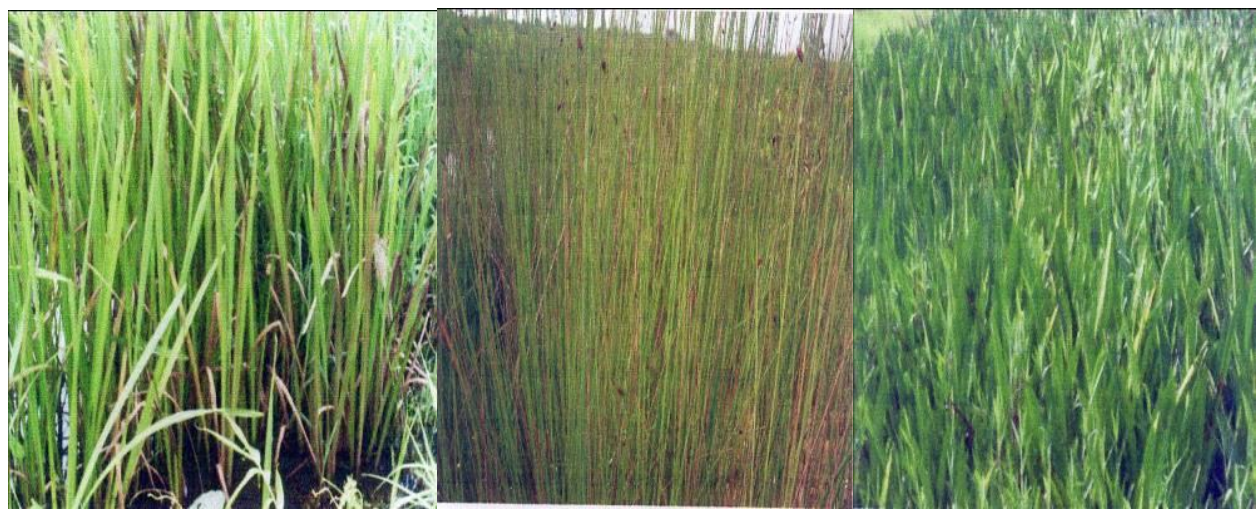

Gambar 2. Jenis rumput yang dijadikan kompos atau pupuk organik.

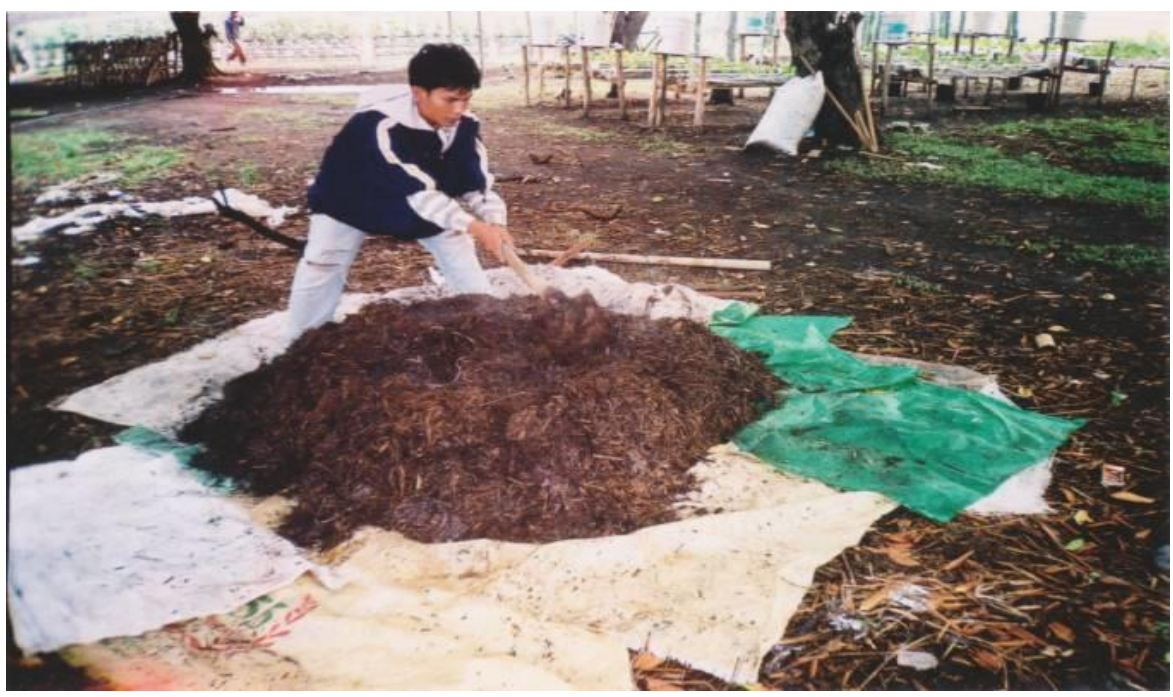

Gambar 3. Pembuatan kompos dari berbagai jenis rumput.

Pembuatan air mineral yang telah Setelah petakan rakit selesai dibuat dikumpulkan kemudian di rangkai dengan kemudian, karung plastik kita letakkan pada menggunakan kawat pada petakan rakit bagian alas/bawah gelas plastik, setelah itu yang terbuat dari kayu hek dengan ukuran baru kita berikan media tanam. lebar $2 \mathrm{~m}$ dan panjang 3m (Gambar 4).

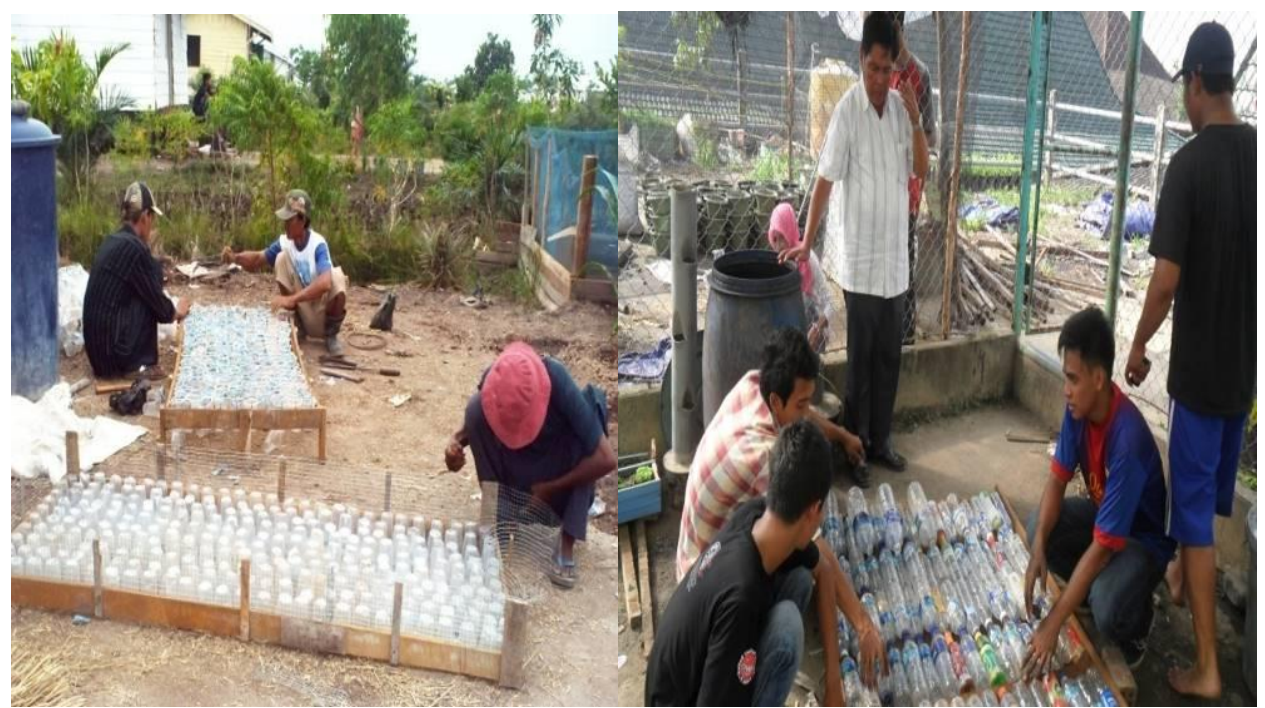

Gambar 4. Pembuatan rakit dari limbah plastik air mineral. 
Media tanam yang akan digunakan yaitu campuran tanah lapisan atas dan rumput kering, kemudian diletakkan di atas rakit setebal $15-20 \mathrm{~cm}$, jarak tanam $20 \mathrm{~cm}$ x $20 \mathrm{~cm}$. Pupuk yang diberikan adalah pupuk organik padat padat berupa kompos berbagai jenis rumput yaitu bakung, gegas, dan purun dengan dosis 5 ton per hektar di berikan pada saat tanam (Gambar 5).
Sebagai pupuk susulan dibarikan pupuk organik cair racikan sendiri yang terdiri dari beberapa jenis tanaman yang direndam dalam air selama 2 minggu Pemberian pupuk cair organik dengan dosis 1 liter bahan pupuk dilarutkan dalam 10 liter air dengan selang waktu 1 minggu sekali setelah tanam.

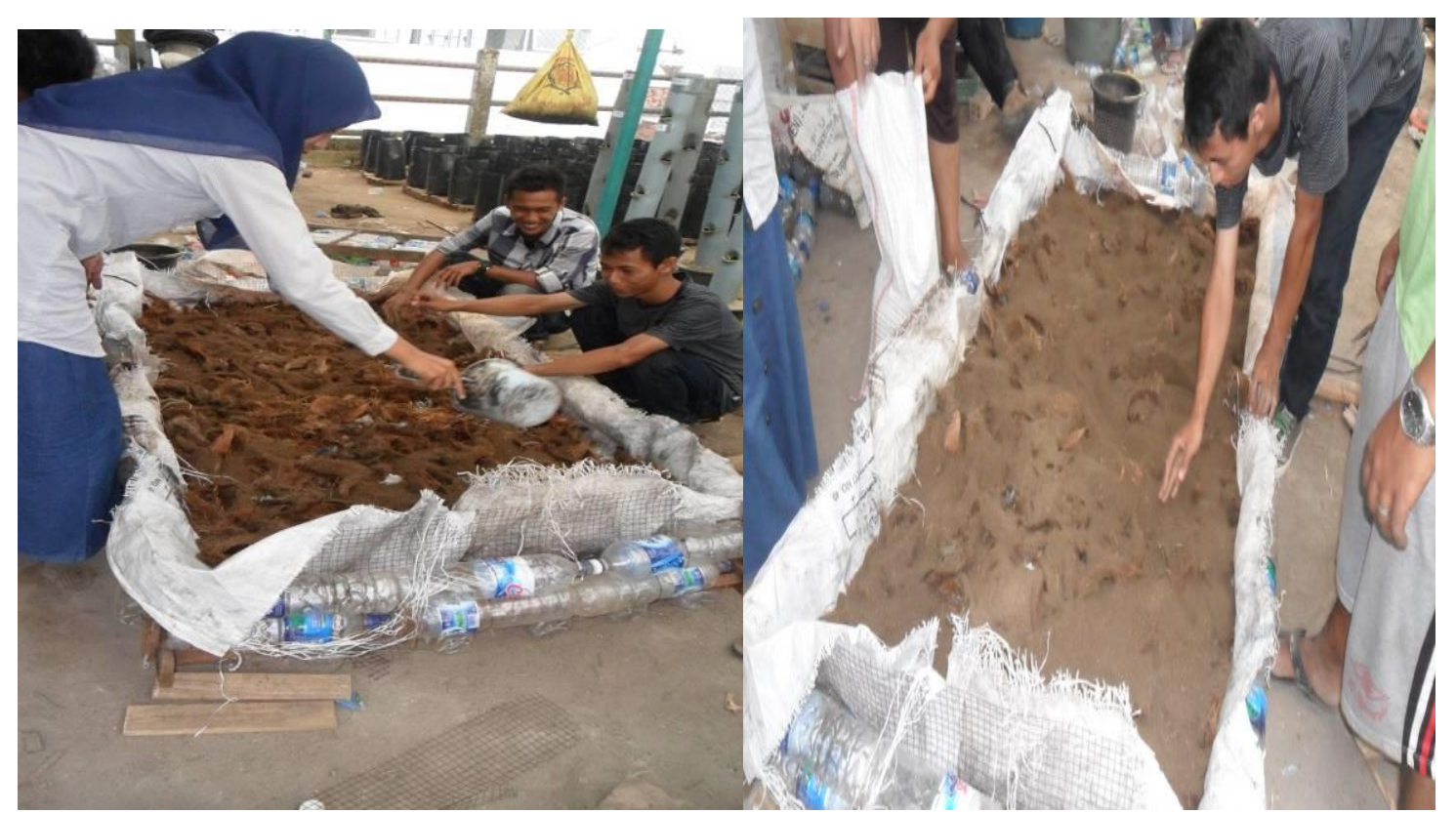

Gambar 5. Pembuatan kompos dari rumput dan pemberian media tanam pada rakit.

Pemeliharaan dilakukan dengan cara pencegahan hama dan penyakit digunakan pestisida organik racikan sendiri, dari bahan ekstraksi beberapa jenis tanaman yang memiliki rasa pedas dan pait serta bau yang diperam selama 2 minggu, dilakukan dengan cara menyemprot tanaman secara rutin seminggu sekali dengan dosis 1 liter bahan pestisida organik dilarutkan dalam 10 liter air, diberikan 1 minggu setelah tanam sampai menjelang panen (Gambar 6).

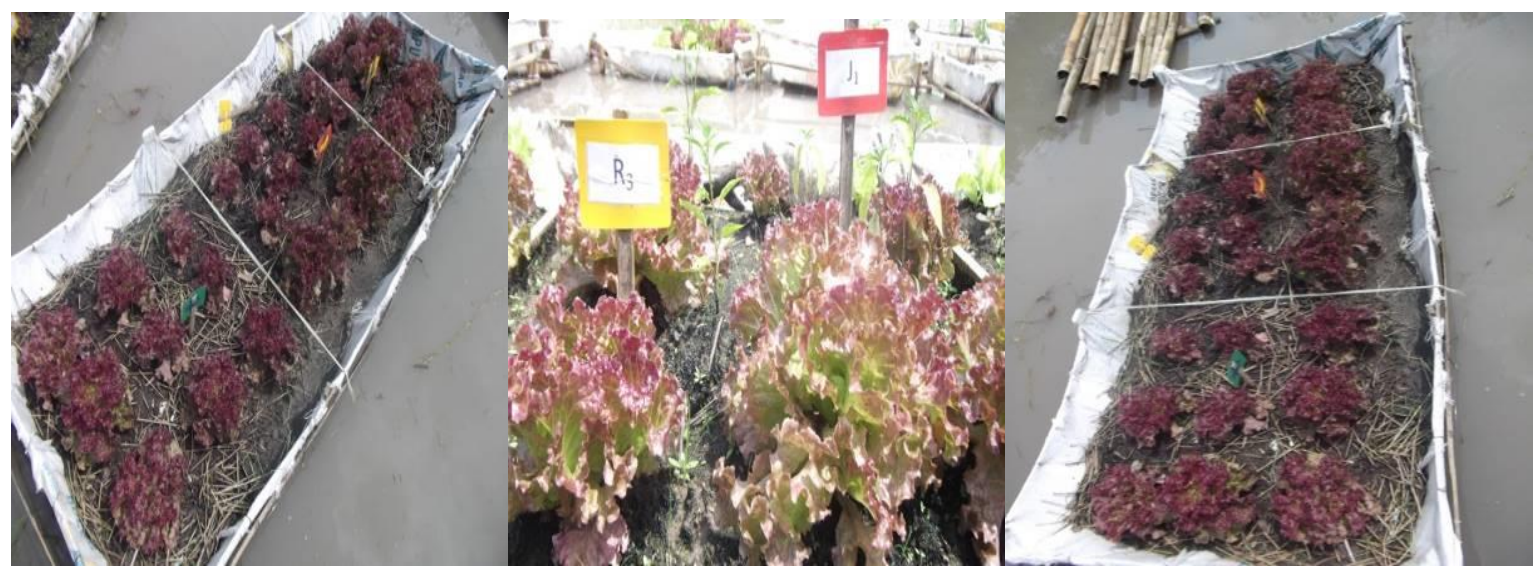

Gambar 6. Kondisi tanaman selada merah keriting di atas rakit. 
Panen dilakukan saat tanaman daun pertanaman (helai), berat berangkasan berumur 30 hari - 45 hari., dengan cara basah (g), dan produksi per rakit (kg) dicabut setiap tanaman. Peubah yang (Gambar 7). diamati adalah tinggi tanaman $(\mathrm{cm})$. Jumlah

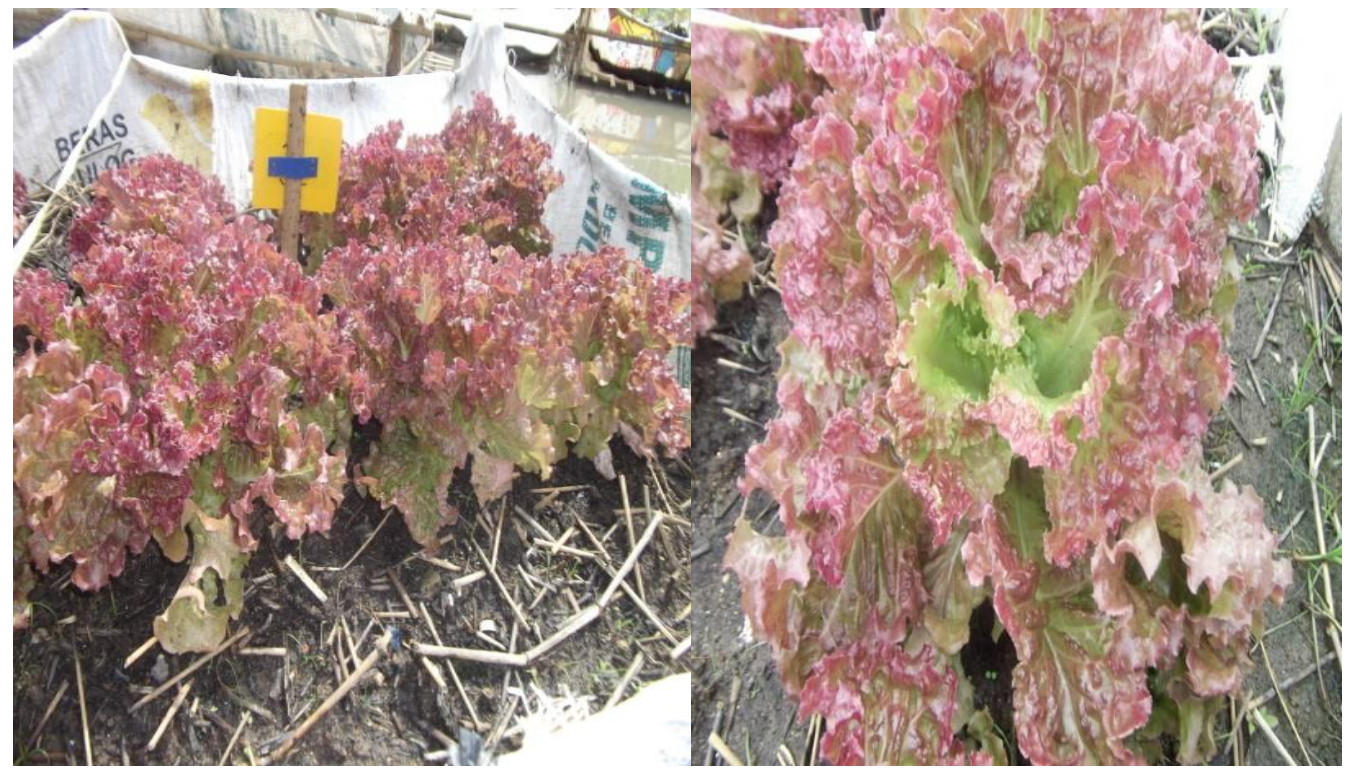

Gambar 7. Kondisi tanaman siap panen.

\section{HASIL DAN PEMBAHASAN}

Perlakuan jenis rakit limbah gelas plastik ukuran $250 \mathrm{ml}$ dan jenis kompos rumput bakung memberikan hasil yang lebih tinggi terhadap semua peubah yang diamati dibandingkan jenis rakit terapung dan jenis kompos rumput rawa yang lainnya yaitu rata-rata tinggi tanaman tertinggi $24.44 \mathrm{~cm}$, rata-rata jumlah daun sebanyak 9,16 tangkai, berat berangkasan basah pertamanan seberat 21.77 gram dan ratarata produksi per rakit sebesar $20,48 \mathrm{~kg}$ (Tabel 1).

Tabel 1. Data pertumbuhan dan produksi tanaman selada merah keriting

\begin{tabular}{lccccc}
\multicolumn{1}{c}{ Kombinasi Perlakuan } & \multicolumn{2}{c}{$\begin{array}{c}\text { Tinggi Tanaman } \\
(\mathrm{cm})\end{array}$} & $\begin{array}{c}\text { Jumlah Daun } \\
\text { (helai) }\end{array}$ & $\begin{array}{c}\text { Berat } \\
\text { Segar/Tanaman } \\
\text { (gram) }\end{array}$ & $\begin{array}{c}\text { Produksi } \\
\text { Total/Rakit }(\mathrm{kg})\end{array}$ \\
\hline Rakit Limbah Gelas & $\mathrm{K} 1$ & $23.38 \mathrm{~b}$ & $7.85 \mathrm{~b}$ & $19.99 \mathrm{a}$ & $18.67 \mathrm{a}$ \\
plastik & $\mathrm{K} 2$ & $24.44 \mathrm{c}$ & $9.16 \mathrm{~b}$ & $21.77 \mathrm{a}$ & $20.48 \mathrm{a}$ \\
Ukuran 250 ml & $\mathrm{K} 3$ & 22.83 & $7.12 \mathrm{~b}$ & $18.55 \mathrm{a}$ & $19.15 \mathrm{a}$ \\
& $\mathrm{K} 1$ & $23.26 \mathrm{~b}$ & $5.64 \mathrm{a}$ & $17.66 \mathrm{a}$ & $17.33 \mathrm{a}$ \\
Rakit Limbah Botol & $\mathrm{K} 2$ & $22.83 \mathrm{~b}$ & $6.46 \mathrm{ab}$ & $16.88 \mathrm{a}$ & $19.20 \mathrm{a}$ \\
plastik ukuran 600 ml & $\mathrm{K} 3$ & $21.83 \mathrm{a}$ & $5.94 \mathrm{a}$ & $15.32 \mathrm{a}$ & $18.45 \mathrm{a}$ \\
Rakit Limbah Botol & $\mathrm{K} 1$ & $21.82 \mathrm{a}$ & $5.28 \mathrm{a}$ & $17.92 \mathrm{a}$ & $16.89 \mathrm{a}$ \\
plastik ukuran & $\mathrm{K} 2$ & $21.94 \mathrm{a}$ & $6.28 \mathrm{~b}$ & $15.66 \mathrm{a}$ & $18.50 \mathrm{a}$ \\
1500 ml & $\mathrm{K} 3$ & $21.33 \mathrm{a}$ & $6.52 \mathrm{~b}$ & $16.11 \mathrm{a}$ & 17,10 \\
BNJ 0,05 & & 1,67 & 0,95 & 10,18 & 10,18 \\
\hline
\end{tabular}


Dari hasil penelitian terlihat bahwa perlakuan jenis kompos rumput bakung menghasilkan Pertumbuhan dan Produksi yang lebih tinggi dibandingkan Perlakuan jenis kompos rumput Rawa lain yaitu Rumput purun $\left(\mathrm{K}_{1}\right)$ dan Rumput Gegas $\left(\mathrm{K}_{3}\right)$, hal ini disebabkan kandungan unsur hara yang terdapat dalam kompos rumput bakung lebih tinggi dibandingkan dengan rumput lainnya, diduga rumput bakung memiliki daun yang lebar dan tebal, dengan demikian akan lebih mudah mengalami proses dekomposisi. Pernyataan ini didukung oleh Muhakka et al. (2006) bahwa, Rumput Bakung secara morfologi tanaman yang memiliki daun yang tebal dan lembut sehingga lebih mudah mengalami proses pelapukan karena banyak mengandung protein. Pendapat ini sesuai dengan hasil analisis laboratorium terlihat bahwa kompos rumput bakung mengandung N-total 2,03 (\%), P-bray 143,30 ppm dan K-dd 4,5 me/100 gram. Rumput purun kandungan N-total 1,55 (\%), P-bray 98,73 ppm dan K-dd 3,01 me/100 gram dan rumput gegas kandungan N-total 1,10 (\%), P-bray 67,48 ppm dan Kdd 2,08 me/100 gram.

Sehingga dengan pemberian pupuk organik (kompos) rumput bakung mampu menyediakan nutrisi bagi tanaman, selain itu didukung oleh media tanam yang mengadung air yang cukup tersedia untuk pertumbuhan dan produksi tanaman selada merah keriting. Menurut Darwin et al. (2007) bahwa dampak pemberian kompos (bokashi) pada media tanam adalah meningkatkan ketersedian unsur hara dalam media tanam, sehingga akan meningkatkan pertumbuhan dan produksi tanaman yang tumbuh diatasnya. Selajutnya Sutanto (2006) bahwa pemberian kompos atau pupuk organic yang mengadung unsur nitrogen pada fase vegetative akan berpengaruh meningkatkan pertumbuhan tanaman. Lebih lanjut dijelaskan oleh Pangaribuan et al. (2011) bahwa pemberian pupuk organik (bokashi) menambah ketersedian unsur hara dalam tanah, jika didukung ketersedian air yang cukup pada media tanamnya.

Menurut Gonzales and Cooperband (2002) bahwa pembertian pupuk organic (bokashi) akan memperbaiki sifat fisik, kimia dan biologi tanah, dengan baiknya sifat tanah akar tanaman akan mampu menembus media tanam sehingga mampu menyerap unsur hara disamping itu kandungan hara dalam media tanam akan meningkat sehingga akan meningkatkan pertumbuhan dan produksi tanaman. Selanjutnya Isnaini (2005) menjelaskan bahwa pemberian pupuk organic baik untuk menjaga kesuburan tanah, baik kesuburan fisik maupun kesuburan kimianya,dengan demikian ketersedian unsur hara dapat ditingkakan sehingga pertumbuhan dan produksi tanaman juga dapat ditingkatkan juga.

Pada perlakuan jenis rakit terlihat bahwa perlakuan limbah gelas plastik ukuran 250ml memberikan respon pertumbuhan dan produksi yang lebih dibandingkan jenis rakit terapung lainnya Hal ini disebabkan pada rakit limbah gelas plastik ukuran $250 \mathrm{ml}$ ada sebagian akar tanaman selada merah keriting menyentuh permukaan air di bagian bawah atau dasar rakitnya, dengan demikian tanaman tidak kekurangan air untuk proses pertumbuhannya. Tanaman selada membutuhkan kondisi media tumbuh yang tidak terlalu banyak airsehingga akar tanamannya tidak tergenangi atau dalam keadaan Lembab tetapi ketersediaan air selalu tersedian saat dibutuhkannya. Kondisi yang demikian ini merupakan kondisi ideal untuk tanaman selada merah keriting, sehingga wajar pertumbuhan dan produksinya lebih baik di bandingkan dengan perlakuan rakit lainnya.

Menurut Ahmed et al. (2002) menjelaskan bahwa pada tanaman hidrofit atau sebagian tanaman mesofit adanya air dibagian akar tak bermasalah karena tanaman mampu beradaptasi, hal ini dikarenakan adanya jaringan aerenkhima di akar sehingga akar tanaman mampu mensuplai oksigen ke bagian tubuh lainnya, 
pembentukan aerenkhima dianggap salah satu hal yang penting untuk adaptasi morfologi tanaman akibat genangan air disekitar akar. Selanjutnya Peeters et al. (2002) bahwa lingkungan yang tidak optimal seperti terjadinya genangan dapat memacu terbentuknya etilen. Etilen memiliki peranan penting dalam pertumbuhan, pertahanan dan kelangsungan hidup tanaman dalam menanggapi lingkungan yang tidak optimal tersebut, akibat peningkatan etilen tanaman mampu mempertahankan hidupnya pada kondisi tergenang. Bila terjadi kerusakan akar akibat genangan air juga dapat menurunkan aktivitas akar sebagai organ yang berfungsi menyerap air dan mineral (Ojeda et al. 2004).

Bila di konversi produksi dalam ton per hektar maka dapat dihitung rata-rata produksi tanaman selada merah keriting per rakit sebesar 28,48 $\mathrm{kg}$ dengan luas rakit 6 $\mathrm{m}^{2}$ dalam 1 hektar terdapat 1600 rakit, produksi per hektar adalah 1600 dikalikan 20,48 kg dibagi faktor koreksi $20 \%$ maka produksinya 26,2 ton/ha. Sedangkan produksi tanaman selada pada lahan kering sekitar 25 ton/hektar (Williams and Peregrine 1993). Wajar saja produksi tanaman selada merah keriting yang ditanam di atas rakitpadakolong pasca penambangan timah walaupun media tanamnya terbatas masih dapat berproduksi sama baiknya dengan produksi tanaman yang di tanam di Lahan Pertanian Konvensional.

\section{KESIMPULAN}

Dari hasil penelitian yang dapat disimpulkan bahwa jenis rakit limbah gelas plastik ukuran $250 \mathrm{ml}$ danjenis kompos rumput bakungmemberikan respon pertumbuhan dan produksi yang lebih baik untuk tanaman selada merah dan penerapan teknologi budidaya tanaman sayuran terapung pada kolong pasca penambangan timah memberikan hasil yang sama dan cendrung lebih tinggi bila dibandingkan dengan sistem budidaya secara konvensional dilahan kering.

\section{UCAPAN TERIMA KASIH}

Ucapan terima kasih disampaikan kepada Rektor Universitas Muhammadiyah Palembang yang telah membiayai Penelitian ini.

\section{DAFTAR PUSTAKA}

Ahmed S, Nawata E, dan Sakuratani T. 2002. Effects of waterlogging at vagetative and reproduktive growth stages on photosyntthesis, leaf water potential and yield in mungbean. Plant Prod. Sci. 5(2):117-123.

Darwin HP, Yasir M, dan Utami NK. 2012. Dampak Bokhasi Kotoran Ternak dalam Pengurangan Pemakaian Pupuk Anorganik pada Budidaya Tanaman Tomat. J. Argon. Indonesia. 40(3):204-210.

Gonzales RF dan Cooperband LR. 2002. Bhakashi effects on the soil physical and field nursery production. Composst Sci.Util.10:226-237.

Isnaini S. 2005. Kandungan Amonium dan Kalium tanah dan serapannya serta hasil padi akibat perbedaan pengelohan tanah yang dipupuk Nitrogen dan Kalium pada tanah sawah. J. Ilmu - Ilmu Pertanian. Ind. 1(6):23-34.

Muhakka, Budianta D, Munandar, dan Abubakar. 2006. Optimalisasi pemberian pupuk organic dan sulfur terhadap produk rumput raja (Pennisetum purpuphoides). $J$. Tanaman Tropika. 9:30-41.

Ojeda M, Schaffer B, dan Davies FS. 2004. Iron nutrition, floding and growth of pond apple trees. Fla. State. Soc. 117:210-215.

Pangaribuan DH, Pratiwi OL, dan Lismawanti. 2011. Pengurangan pemakaian pupuk anorganik dengan penambahan bokashi seresah 
tanaman pada budidaya tomat. $J$. Agron. Indonesia 39: 173-179.

Peeter AJM, Cox CH, Benschop JJ, Vreeburg RAM, Bou J, dan Voesenek LACJ. 2002. Submergence research using Rumex palustris as model; looking back and going forward. J. Expe. Bot. 53(368):391-398.

PT. Timah. 2003. Laporan Kegiatan Tahunan PT. Timah Tbk. Pangkal Pinang Provinsi Bangka-Belitung.

Rukmana R. 2004. Bertanam Selada dan Andewi. Yogyakarta: Kanisius.

Syafrullah, Moelyohadi Y, Rosmiah, Hawalid H, dan Syahziliadi. 2004,
Penerapan Teknologi Rakit Terapung dalam Budidaya Tanaman Pangan dan Sayuran di Lahan Lebak Tegenang. Kerja Sama Balai Pengkajian Teknologi Pertanian. Sumatera Selatan.

Sutanto R. 2006. Penerapan Pertanian Organik. Pemasyarakatan dan Pengembangannya. Yogyakarta: Kanisius.

Williams CN dan Peregrine WTH. 1993. Produksi Sayuran di Daerah Tropika. Terjemahan oleh: S. Ronoprawiro dan G. Tjitrosoepomo. Yogyakarta, Indonesia: Gadjah Mada University Press. 